\title{
LEGAL MONOPOLY: PATENTS AND ANTITRUST LITIGATION IN U.S. MANUFACTURING, 1970-1998
}

\author{
B. Zorina Khan
}

Working Paper 7068

http://www.nber.org/papers/w7068

\author{
NATIONAL BUREAU OF ECONOMIC RESEARCH \\ 1050 Massachusetts Avenue \\ Cambridge, MA 02138 \\ April 1999
}

Presented at the NBER Conference "The Patent System and Innovation" funded by the Alfred P. Sloan Foundation via a grant to the NBER Project on Industrial Technology and Productivity. The views expressed in this paper are those of the authors and do not reflect those of the National Bureau of Economic Research.

(0 1999 by B. Zorina Khan. All rights reserved. Short sections of text, not to exceed two paragraphs, may be quoted without explicit permission provided that full credit, including ${ }^{\circ}$ notice, is given to the source. 
Legal Monopoly: Patents and Antitrust Litigation

in U.S. Manufacturing, 1970-1998

B. Zorina Khan

NBER Working Paper No. 7068

April 1999

ABSTRACT

This paper presents an empirical analysis of the relationship between patenting, innovation, and federal antitrust enforcement towards firms in the manufacturing sector. I examine whether the likelihood of antitrust litigation is influenced by patent histories and R\&D expenditures, after controlling for other firm-specific variables including size and likelihood of antitrust charges for medium and large firms. Smaller firms with faster sales growth are also more likely to be charged with antitrust violations.

B. Zorina Khan

Department of Economics

Bowdoin College

Brunswick, ME 04011

bkhan@bowdoin.edu 


\section{INTRODUCTION}

The American judiciary in the nineteenth century deprecated monopoly, but celebrated the grant of property rights in patents. ${ }^{1}$ Judges did not recognize patents as monopolies, arguing that patentees added to social welfare through innovations which had never existed before, whereas monopolists secured to themselves rights that already belong to the public. ${ }^{2}$ The passage of the Sherman Act in 1890 was associated with a populist emphasis on the need to protect the public from corporate monopolies, including those based on patent protection. ${ }^{3}$ Numerous lawsuits, articles and books since then have debated whether antitrust policies, which are designed to suppress monopolization, are antithetical to policies that grant exclusive property rights in inventions.

Researchers who support the hypothesis of a conflict typically describe antitrust lawsuits and identify the large number which seem to hinge on patent issues or to involve corporations regarded as technological leaders. The roster ranges from landmark cases in the early decades of the 20th century, such as those against American Tobacco, John Deere \& Co., American Can and International Harvester, through to the numerous cases since 1970 against prominent innovators such as IBM, Xerox, Eastman Kodak and, most recently, Intel and Microsoft. ${ }^{4}$ Some of the studies in this vein claim that antitrust officials have evinced "almost unbroken hostility towards patents." obtaining static (antitrust) gains at the expense of dynamic (technological) efficiency. ${ }^{6}$

Proponents of the "no conflict" view specify distinctions between the justifiable exercise of patent power and unjustifiable misuse that is subject to antitrust action; countercite other cases upholding patent rights in the context of antitrust charges; or else 
point to the lack of supporting evidence. ' Ward Bowman refuted the notion of a conflict on conceptual grounds, arguing that the objective of both policies is to increase social welfare by providing consumers with the most goods at the lowest cost. ${ }^{8}$ Federal antitrust agencies have likewise contended that there is "no basic incompatibility or irreconciliable conflict between the patent laws and the antitrust laws," because both have the objective of promoting competition and enhancing social utility. ${ }^{9}$ The question of conflict is easy to dismiss in specific circumstances such as patent misuse and fraud. For instance, in Pfizer v. FTC 394 U.S. 920 (1969), it was found that Pfizer and American Cyanamid had deceived the Patent Office and used the patent property to engage in monopolization of the tetracycline market. Similarly, the FTC challenged a 1998 merger between Summit Technologies and VISX because of patent misuse, and proposed that a key VISX patent should be overturned. ${ }^{10}$ Plaintiffs in antitrust disputes can also bring charges based on "predatory innovation" that has the objective of eliminating competition. ${ }^{11}$ However, such cases involve clearly unacceptable practices associated with patent ownership, and do not bear on questions such as whether technological innovators may legitimately gain market power associated with patent ownership, and thus increase the likelihood that complaints against them are filed under antitrust laws.

This study considers the question of whether greater technological innovativeness is associated with closer scrutiny by antitrust enforcement agencies. Specifically, I examine whether technological innovation influences the probability of an antitrust action. Case studies and theoretical insights are important and informative, but the issue of the relationship between patent and antitrust enforcement is only partially illuminated by these 
methods. Although quantitative data are likely to exhibit other limitations, a systematic assessment of antitrust charges over time at least provides another perspective that may shed some light on the patent-antitrust debate. Despite the voluminous literature on antitrust litigation and its relationship to intellectual property, most empirical work has been directed towards other antitrust issues and few towards the patent-antitrust interface. Richard Posner made an important contribution in 1970 when he presented simple descriptive statistics regarding overall historical trends in antitrust enforcement at the industry level. Some researchers have used his industry level data to examine the determinants of antitrust activity, and, apart from sales, found a negligible relationship between economic factors and numbers of charges brought across industries. ${ }^{12}$ This is hardly surprising, since antitrust charges are brought against firms, and not against industries. Other studies have analyzed specific antitrust violations such as price fixing and mergers, or on the political economy of federal agencies such as the FTC. ${ }^{13}$

This paper therefore presents an empirical analysis of the patent-antitrust issue in the manufacturing sector between 1970 and 1998. I investigate the influence of innovation on the likelihood of federal government antitrust charges, controlling for firm specific factors such as firm size, sales growth and advertising intensity. It should be noted that the underlying concern is not so much to ascertain whether there is an inherent or actual patent-antitrust conflict. Rather, this study recasts the debate by considering whether innovative firms that engage in high levels of patenting or research and development antitrust are more likely to be engaged in federal antitrust litigation. I also assess an example, in the area of $R \& D$ joint ventures, where antitrust policy appears to have 
influenced the rate and direction of inventive activity.

The first section of the paper summarizes aggregate trends in antitrust litigation initiated by the Federal Trade Commission and the Department of Justice between 1970 and 1998. The second section describes a dataset of firms that were involved in federal restraint of trade lawsuits and a control sample that form the basis for subsequent analysis. The third section examines patterns of patenting and innovation at the firm level, and relates these patterns to variation over time, firm characteristics, and interindustry effects. The data are then used to assess whether innovativeness in the form of R\&D and patenting tends to increase the likelihood of antitrust charges within a given industry, after controlling for other variables that might affect the tendency to antitrust scrutiny. The final section discusses whether antitrust policy has influenced firm behaviour, by considering patterns of filing of joint ventures in research and development, under the National Cooperative Research and Production Act which provides limited relief from antitrust sanctions.

Clearly, if firms with more extensive patent portfolios experience a greater likelihood of antitrust scrutiny, it holds serious implications for the future of the patent system. Significantly, sanctions under the patent law are far less stringent than those of antitrust: patentees who are charged under antitrust law may face treble damages, forced divestures and compulsory licensing, compared to the simple invalidation of the patent grant under patent laws. Thus, if firms perceive that higher patenting is associated with a higher likelihood of antitrust charges, a rational response would be to reduce the propensity to patent, and to attempt to appropriate returns outside of the patent system. It should be noted that this study is not intended to prescribe whether optimal policy should be directed 
towards strengthening antitrust enforcement or towards furthering the rights of patent holders. However, legal rules are unlikely to be wealth-maximizing if they create inconsistent incentives, so the results bear implications for both federal industrial and intellectual property policies.

\section{AGGREGATE ANTITRUST LITIGATION AND THE ANTITRUST DATASET}

The major antitrust statutes -- the Sherman Act, Federal Trade Commission Act, Clayton Act, Hart-Scott-Rodino Act -- have the basic objective of regulating business and controlling firms which engage in anticompetitive practives, in order to promote social welfare. Figure 1 shows all antitrust cases, both federal and private, filed in U.S. district courts between 1975 and 1997. Both series reveal a precipitous drop in total district court filings, but the share of government lawsuits increased somewhat after 1985, partly because of more stringent requirements that the courts imposed on private litigants. I chose to focus on federal government litigation in this study, because the rationale for private antitrust litigation is likely to be more difficult to disentangle and interpret. Moreover, private actions may be related to government charges, as in cases where private plaintiffs use federal complaints as a signal to free-ride on federal investigation expenditures and to try to obtain damages or injunctive relief from alleged harm that the federal defendant may have caused competitors. ${ }^{14}$

The Department of Justice (DOJ) and the Federal Trade Commission (FTC) do not publish reports of antitrust statistics in a form that can be used for systematic economic 
Figure 1

Private and Government Antitrust Cases, 1975-1997 (percent)

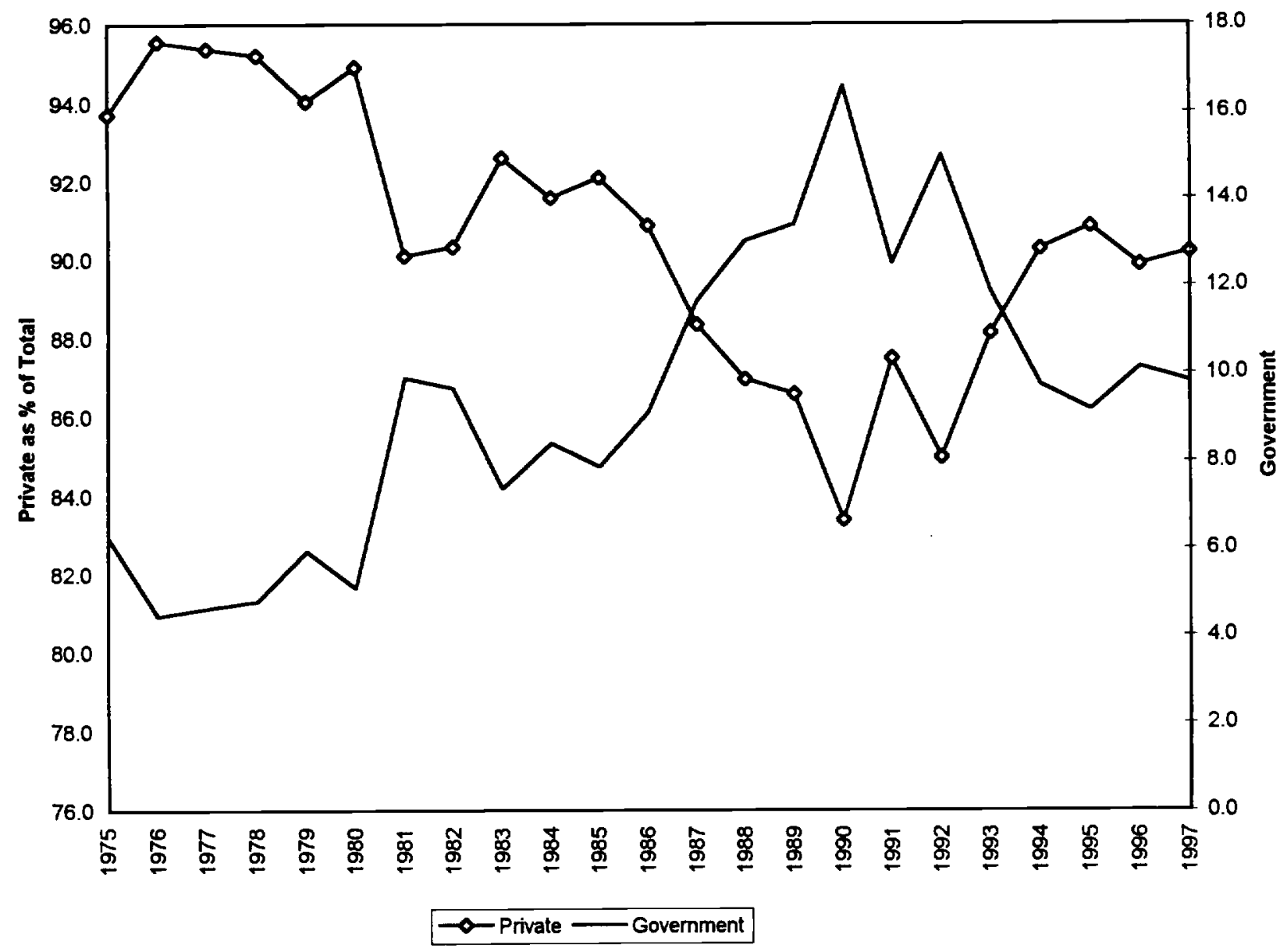

Notes: The figure includes total antitrust cases filed in U.S. district courts. U.S. government cases include both civil and criminal charges, in which the government was either plaintiff or defendant. Source: Administrative Office of the United States Courts, Annual Report of the Director, various years [Washington, DC, USGPO]. 
analysis. Instead, these data must be retrieved from the $\mathrm{CCH}$ Trade Regulation Reports. The Reports typically include several entries relating to one action, some of them listed across several years. The Federal Trade Commission reports summaries of cases in the "FTC Docket of Complaints" of The Trade Regulation Reports. The Dockets are not very informative, comprising the name of the firm, frequently the good produced, and the charges. I concatenated these FTC complaints to obtain a list of distinct actions for each firm. Similary, I compiled the aggregate DOJ information by individual action from 1970 through 1998, categorizing the cases by four-digit SIC code, and noting the issue, outcome and year of decision when that could be traced. Once the sample was assembled, I obtained further information about individual cases from the TRADE library of Lexis/Nexis. The resulting data set can be used to track broad changes in federal antitrust litigation and policy over time and industry, although the focus of this paper is primarily on the influence of patenting on antitrust litigation.

Between 1970 and 1993 the Department of Justice (DOJ) filed 1293 charges. ${ }^{15}$ The majority of cases related to allegations of bid-rigging in the construction industry, with numerous defendants listed in each charge. In keeping with its stated mission, the DOJ's second priority is the prosecution of price-related restraints of trade. Almost one half (47 percent) of all non-bidrigging charges deal with pricing issues, especially the per se illegal criminal price-fixing cases which tend to be charged and summarily decided in the same year. In contrast, the 1673 FTC consent decrees predominantly involve false advertising and deceptive business practices. ${ }^{16}$ The more economically based investigations address issues relating to mergers, pricing and restraint of trade actions. Some have argued that the work 
of the two agencies is largely duplicative, but agency employees indicate that they engage in a division of labour by industry. The consent decrees support this, since the DOJ's cases focus on construction, the service sector, food, chemicals and the petroleum industries. The FTC historically charged firms in textiles and financing (such as credit collection companies), but the agency has recently increased litigation against firms in software, computers, and high technology, and has sponsored hearings on global and innovation-based competition. $^{17}$

From these aggregate data I selected my antitrust sample, which comprises all manufacturing firms that were primary defendants in general trade restraint charges filed by the FTC and DOJ between 1970 and the present. ${ }^{18}$ Figure 2 illustrates the time series of federal antitrust complaints that I compiled as a subset of the aggregate data described above. The antitrust sample totals approximately 500 companies involved in 547 cases, and exclu des those charged with "noneconomic" antitrust torts such as deceptive advertising and misleading trade practices. This number was reduced to 426 actions against publicly traded firms that were included in the Compustat files, in order to obtain a time series of financial data such as income, balance sheet and stock market values. The antitrust charge specified the product market that was the subject of the action, so it was possible to allocate each charge to an industry at the four-digit SIC level. Each firm in the antitrust sample was then matched by 4-digit SIC code and the year in which the lawsuit was filed with a control firm that had not been involved in antitrust litigation between 1950 and 1998 (see Appendix). 
Figure 2:

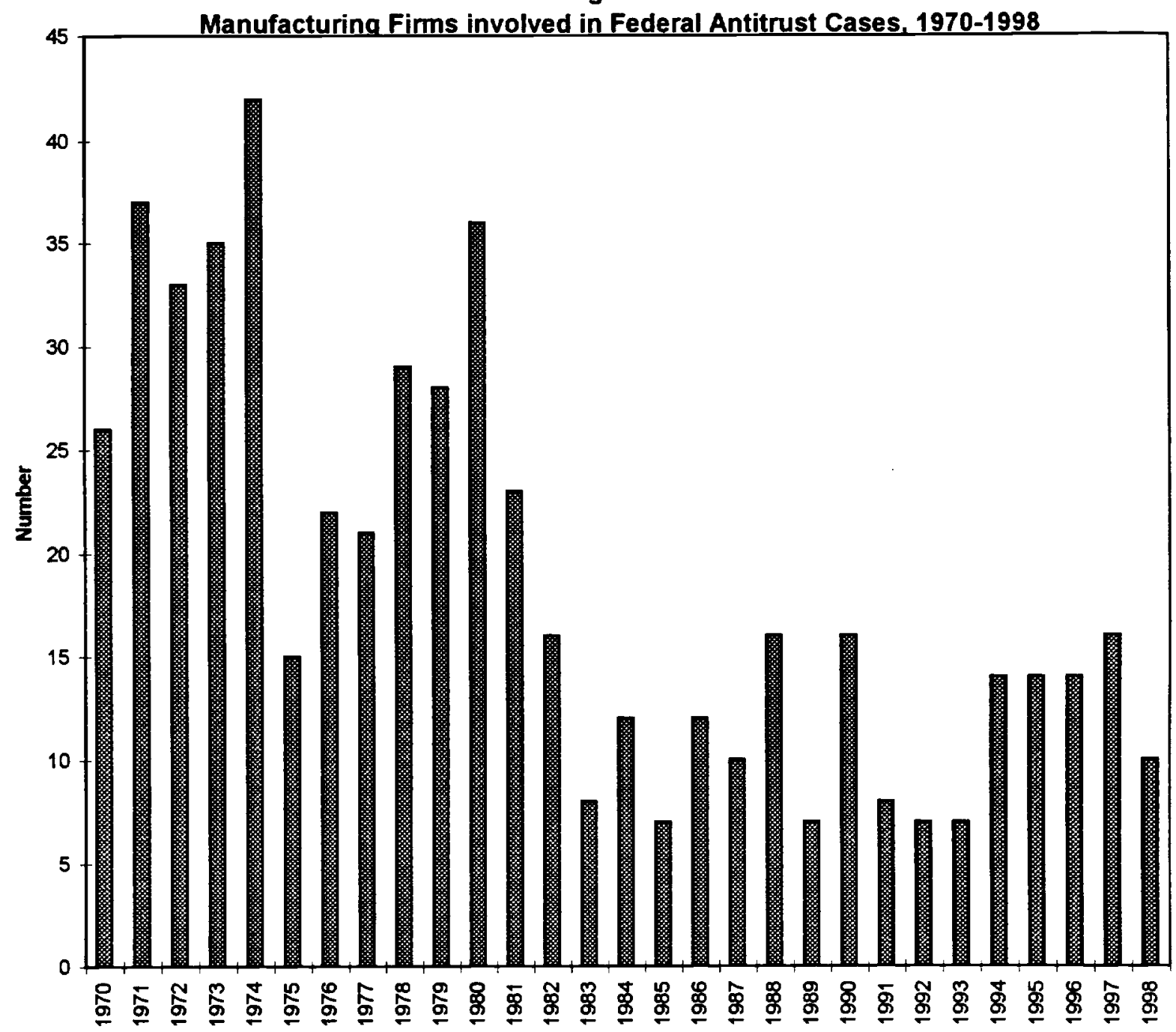

Notes: See text for description of sample, which includes charges filed by the Federal Trade Commission and the Department of Justice Antitrust Division. 


\section{PATTERNS OF INNNOVATION}

In order to better understand the link between antitrust and innovation, this section relates R\&D and patenting to firm level characteristics and to industrial composition. ${ }^{19}$ The "Schumpeterian hypothesis" is typically characterized as proposing a positive relationship between firm size, industry concentration, and innovation. ${ }^{20}$ In the antitrust dimension, this model implies that innovative enterprises may attract antitrust attention because they are more likely to be dominant or large relative to the industry. The concentration of patenting in large corporations has long been noted, and designated the "monopolization of patent monopolies."21 Fritz Machlup felt that patent policies by large firms assured them of "almost unlimited monopoly power."122 These statements are based on the view that patents serve to create and preserve market power through barriers to entry, especially since patenting around the invention and patent litigation by potential entrants can be costly and risky strategies. Acs and Audretsch tested a modification of the usual Schumpeterian model and found that large firms tended to have a innovative advantage in capital intensive, concentrated, and advertising intensive industries, whereas smaller firms had a comparative advantage in very innovative industries, and in more competitive markets. ${ }^{23}$ Some contend that such research findings highlight the need to strengthen antitrust laws to deal with large patent portfolios. For instance, it has been suggested that antitrust laws should inhibit firms from accumulating large stocks of patents through policies such as a progressive tax..$^{24}$ Others have supported the introduction of requirements such as compulsory patent licensing or working the patent, under the guise of antitrust policy, although historically both the courts and the makers of U.S. patent policies have resisted imposing restrictions on the 
rights of the owners of intellectual property. ${ }^{25}$

In order to examine the relationship between patenting and antitrust, it is useful to first of all consider the types of firms that engage in patenting. Since there is high variance in the annual numbers of patents issued to a firm, I use instead the accumulated stock of patents assigned to the firm in the five years up to and including the year of the antitrust charge. ${ }^{26}$ These included patent holdings by firms such as General Electric (4378 patents between 1977 and 1981), Westinghouse (1923 between 1981 and 1985), Dow Chemical (1894 between 1983 and 1987), and Alliant Techsystems (82 patents, 1990 through 1994). The simple statistics presented in Table 1 are consistent with other studies using patent data and are consistent with the "Schumpeterian hypothesis." The data indicate that patenting varies positively with firm size in the antitrust sample as well as the control sample. Patenting by antitrust firms is significantly higher across all size categories, both in terms of levels and relative to total assets and sales. However, the summary statistics in Table 1 also indicate that the antitrust firms tend to be much larger than the control sample. This reflects the significance of large size (and hence of market share) in motivating antitrust lawsuits: in some concentrated industries (such as automobiles and rubber tires) it was difficult to find any firms which had existed in the same period and had not been charged with antitrust violations after 1950. However, one might be concerned about selection bias in the control sample. In order to indicate how sensitive the results are to differences in size the analysis reported below allows coefficients to vary across firm size. I also tested the robustness of the results by redoing the analysis after eliminating from the dataset the top 100 firms in terms of size. 
TABLE 1

DESCRIPTIVE STATISTICS: ANTITRUST AND MATCHED SAMPLE

\begin{tabular}{|c|c|c|}
\hline & ANTITRUST & MATCHED \\
\hline LARGE FIRMS & $\begin{array}{l}\text { Means } \\
(N=110)\end{array}$ & $\begin{array}{l}\text { Means } \\
(\mathbf{N}=5)\end{array}$ \\
\hline Patents & $\begin{array}{l}(N=110) \\
881.41\end{array}$ & $\begin{array}{l}(N=5) \\
27.00\end{array}$ \\
\hline R\&D Intensity & 0.026 & 0.005 \\
\hline Advertising Intensity & 0.009 & 0.001 \\
\hline Excess Market Valuation & 1.209 & 1.442 \\
\hline \multicolumn{3}{|l|}{ Intellectual Property } \\
\hline Litigation & 85.04 & 2.000 \\
\hline $\mathrm{R} \& \mathrm{D}=0$ & 0.145 & 0.600 \\
\hline Intangible/Total Assets & 0.061 & 0.006 \\
\hline Sales Growth & 0.151 & 0.156 \\
\hline Profit & 0.056 & 0.056 \\
\hline Capital Intensity & 0.095 & 0.060 \\
\hline Total Assets (real) & 21717 & 7609 \\
\hline MEDIUM FIRMS & $(\mathrm{N}=175)$ & $(\mathrm{N}=50)$ \\
\hline Patents & 137.1 & 55.82 \\
\hline R\&D Intensity & 0.202 & 0.012 \\
\hline Advertising Intensity & 0.022 & 0.006 \\
\hline Excess Market Valuation & 1.379 & 1.222 \\
\hline \multicolumn{3}{|l|}{ Intellectual Property } \\
\hline Litigation & 23.92 & 8.060 \\
\hline $\mathrm{R} \& \mathrm{D}=0$ & 0.297 & 0.400 \\
\hline Intangible/Total Assets & 0.048 & 0.029 \\
\hline Sales Growth & 0.143 & 0.115 \\
\hline Profit & 0.059 & 0.046 \\
\hline Capital Intensity & 0.083 & 0.084 \\
\hline Total Assets (real) & 2261 & 1287 \\
\hline SMALL FIRMS & $(\mathrm{N}=114)$ & $(\mathrm{N}=332)$ \\
\hline Patents & 55.14 & 9.371 \\
\hline R\&D Intensity & 0.019 & 0.013 \\
\hline Advertising Intensity & 0.016 & 0.020 \\
\hline Excess Market Valuation & 1.650 & 1.244 \\
\hline \multicolumn{3}{|l|}{ Intellectual Property } \\
\hline Litigation & 12.63 & 2.421 \\
\hline$R \& D=0$ & 0.561 & 0.617 \\
\hline Intangible/Total Assets & 0.056 & 0.036 \\
\hline Sales Growth & 0.148 & 0.033 \\
\hline Profit & 0.058 & 0.012 \\
\hline Capital Intensity & 0.075 & 0.067 \\
\hline Total Assets (real) & 228 & 131 \\
\hline
\end{tabular}


ALL FIRMS

Patents

R\&D Intensity

Advertising Intensity

Excess Market Valuation

Intangible Assets

Intellectual property

litigation

$R \& D=0$ Dummy

Intangible/Total Assets

Sales Growth

Profit rate

Capital Intensity

Employees

Total Assets (real)

Number of Firms
ANTITRUST

Std Dev

767.8

0.041

0.035

1.002

2020.24

70.79

0.471

3.14

0.589

0.034

0.049

0.019

0.069

5.156

458

17995

426

MATCHED

Std Dev

45.93

0.032

0.051

0.840

27.72

6.47

0.493

0.070

0.477

0.302

0.051

60.946

120.72

10.83

1146

Notes and Sources: see Appendix for definition of variables and sources. 
The smaller antitrust firms have a greater patenting intensity relative to total assets and to research and development than the larger antitrust firms. Both large and medium antitrust firms tend to have higher research and development and advertising expenditures relative to total assets and sales compared to the control sample, whereas smaller firms in both samples were more similar in these dimensions. Medium and small firms also reported similar physical capital intensity across samples, but the antitrust firms are characterized by higher levels of intangible assets relative to total assets, have higher sales growth, and greater profitability. The control firms tended to have lower excess market valuations (ratios of market value of the firm to total assets that proxy for Tobin's $Q$ ), which may be interpreted as a crude measure indicating lower market power. The record of higher intellectual property litigation for antitrust firms is somewhat ambiguous, since it may reflect higher valued patents, or greater competitiveness in defending or enforcing the firm's intellectual property. The latter might be related to anticompetitive strategies, but the negligible simple correlation (Table 2) between the proxy for market power and litigation does not support the idea that intellectual property litigation is related to market dominance.

Figure 3 is consistent with the idea that antitrust firms are more innovative with regard to patenting compared to the general population of firms, since their record of average annual patent grants is consistently higher. Although there is still a lot of noise in the time series of average annual patents granted, a declining trend was followed by a recent surge in patents granted to antitrust firms charged in the 1990s. This could be due to the increase in the importance of technology-intensive industries relative to total economic 
TABLE 2

CORRELATION ANALYSIS OF INTANGIBLE ASSETS

ANTITRUST AND MATCHED SAMPLES

VARIABLES

ANTITRUST

MATCHED

$\underline{\log (\text { Patents) }}$

Excess Market Valuation

$-0.015$

$0.124 *$

IP Litigation

$0.531^{*}$

$0.583^{*}$

Capital Expenditures

$0.407^{*}$

$0.139 *$

Capital Invested

$0.402 *$

$0.185 *$

R\&D Intensity

$0.196 *$

$0.283 *$

Sales Growth

0.017

0.068

Advertising Intensity

$-0.073$

$-0.060$

Advertising Intensity

Excess Market Valuation

$0.214^{*}$

0.013

Profit Rate

$0.125 *$

$-0.619 *$

R\&D Intensity

0.066

$-0.019$

$\underline{\text { R\&D Intensity }}$

Excess Market Valuation

$0.214 *$

$0.462 *$

Profit Rate

$-0.050$

$-0.075$

IP Litigation

$0.128 *$

$0.106 *$

Intellectual Property Litigation

Profit Rate

$0.098 *$

0.012

Excess Market Valuation

0.044

0.077

Excess Market Valuation

Profit Rate

$0.200^{*}$

$0.220 *$

Sales Growth

$0.192 *$

0.040

Notes:

* = significant at least at the 1 percent level.

See Appendix for definition of variables and sources. 
Figure 3

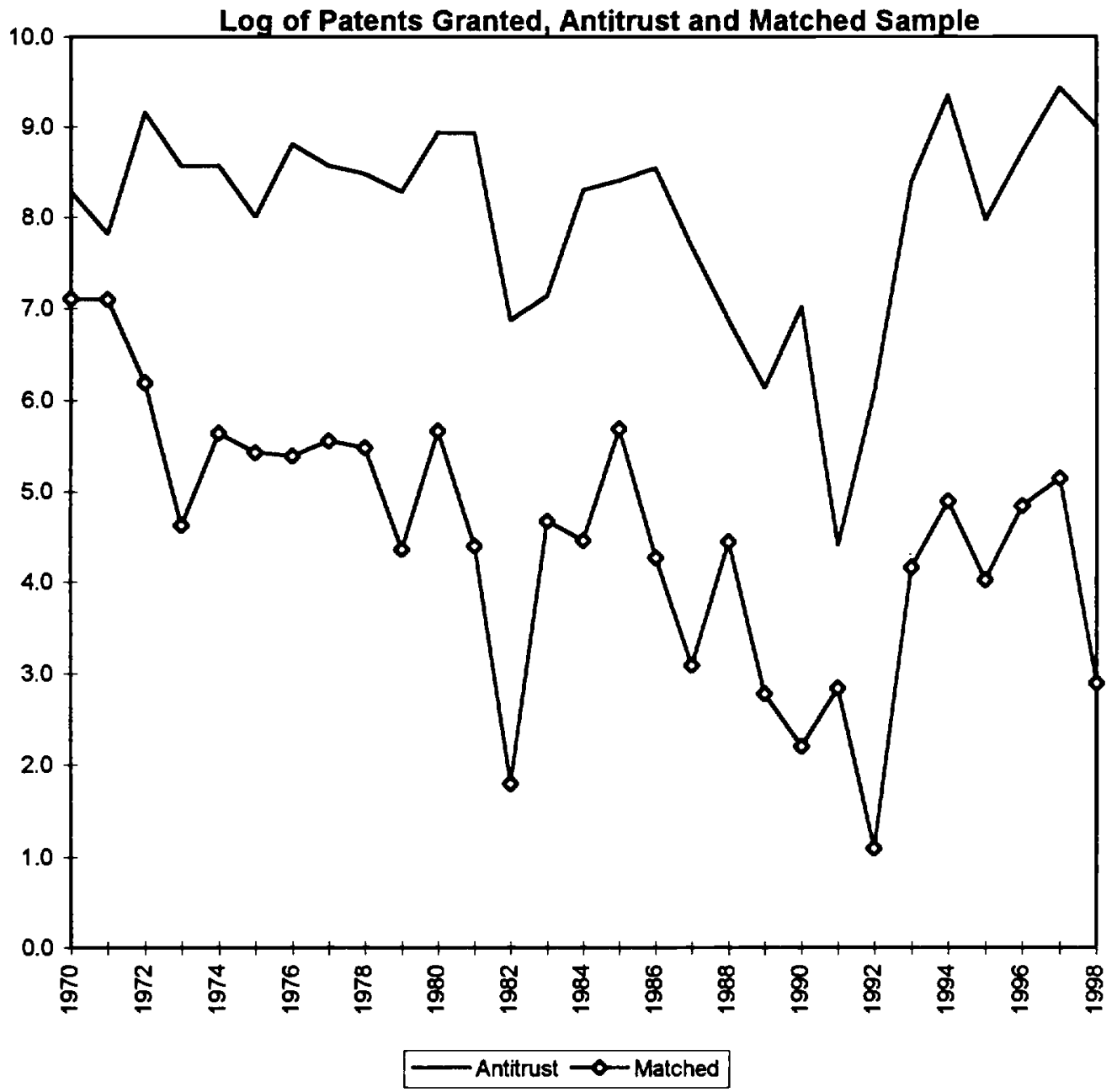

Notes: The horizontal axis refers to the year in which the antitrust charge was filed, and the data series reflect the log of total patents granted to firms in each sample. For further information on the samples, see the text. 
output, or to greater antitrust attention being paid to firms or industries that are more innovative. The former hypothesis seems more plausible since the matched sample experiences similar patterns in patenting. Because firms are matched by industry, these data reveal within industry variation in antitrust activity rather than interindustry differences. However, Table 3 indicates an increase in the number of firms charged with antitrust violations in the chemical, pharmaceutical, computer and machinery, and professional and scientific equipment industries, industries which are generally regarded as more technologically innovative. In order to explore the relationship between patenting and antitrust, it is useful to further examine the factors that influence patenting at the firm level.

Table 4 reports the results of OLS regressions with the log of the five year patent stock as the dependent variable. Patenting shows a downward trend, and is significantly higher for larger firms and for firms that were involved in antitrust. However, apart from size, none of the market power variables is significant. Separate regressions for firms of small, medium and large size (not reported) indicate that much of the patenting by smaller firms appears to be non-firm specific, for only 10 percent of variation in their patenting is explained by the independent variables, compared to 55-66 percent for medium firms. Higher research and development is associated with higher patenting, with significantly positive coefficients on current $R \& D$ and the second $R \& D$ lagged term (although the significance of the second term falls when total assets is included), suggesting that patents in these firms may tend to arise early in the development stage. The relationship between patenting and R\&D appears to be non-linear, since the coefficient on the squared R\&D term is positive and significant. However, the latter result does not hold when the 
TABLE 3

INDUSTRIAL DISTRIBUTION OF PATENTS GRANTED

\begin{tabular}{|c|c|c|c|c|c|c|}
\hline \multirow[t]{2}{*}{ INDUSTRY } & \multicolumn{4}{|c|}{ ANTITRUST } & \multicolumn{2}{|c|}{ MATCHED } \\
\hline & $1970 \mathrm{~s}$ & $1980 \mathrm{~s}$ & $1990 \mathrm{~s}$ & $1970 \mathrm{~s}$ & $1980 \mathrm{~s}$ & $1990 \mathrm{~s}$ \\
\hline $\begin{array}{l}\text { Motor vehicles and } \\
\text { transportation equipment }\end{array}$ & $\begin{array}{l}425 \\
(18)\end{array}$ & $\begin{array}{l}522 \\
(8)\end{array}$ & $\begin{array}{l}516 \\
(8)\end{array}$ & $\begin{array}{l}32 \\
(17)\end{array}$ & $\begin{array}{l}18 \\
(8)\end{array}$ & $\begin{array}{l}9 \\
(8)\end{array}$ \\
\hline Drugs and chemicals & $\begin{array}{l}413 \\
(27)\end{array}$ & $\begin{array}{l}418 \\
(22)\end{array}$ & $\begin{array}{l}363 \\
(23)\end{array}$ & $\begin{array}{l}25 \\
(25)\end{array}$ & $\begin{array}{l}10 \\
(20)\end{array}$ & $\begin{array}{l}4 \\
(20)\end{array}$ \\
\hline Communication equipment & $\begin{array}{l}423 \\
(17)\end{array}$ & $\begin{array}{l}804 \\
(10)\end{array}$ & $\begin{array}{l}775 \\
(9)\end{array}$ & $\begin{array}{l}37 \\
(17)\end{array}$ & $\begin{array}{l}18 \\
(9)\end{array}$ & $\begin{array}{l}15 \\
(9)\end{array}$ \\
\hline Food and kindred products & $\begin{array}{l}96 \\
(41)\end{array}$ & $\begin{array}{l}20 \\
(14)\end{array}$ & $\begin{array}{l}66 \\
(11)\end{array}$ & $\begin{array}{l}6 \\
(42)\end{array}$ & $\begin{array}{l}1 \\
(13)\end{array}$ & $\begin{array}{l}1 \\
(9)\end{array}$ \\
\hline Lumber and paper products & $\begin{array}{l}35 \\
(17)\end{array}$ & $\begin{array}{l}90 \\
(5)\end{array}$ & $\begin{array}{l}300 \\
(1)\end{array}$ & $\begin{array}{l}16 \\
(16)\end{array}$ & $\begin{array}{l}2 \\
(5)\end{array}$ & $\begin{array}{l}0 \\
(1)\end{array}$ \\
\hline Machinery & $\begin{array}{l}343 \\
(11)\end{array}$ & $\begin{array}{l}1130 \\
(8)\end{array}$ & $\begin{array}{l}506 \\
(16)\end{array}$ & $\begin{array}{l}88 \\
(10)\end{array}$ & $\begin{array}{l}39 \\
(8)\end{array}$ & $\begin{array}{l}9 \\
(12)\end{array}$ \\
\hline Metals & $\begin{array}{l}91 \\
(25)\end{array}$ & $\begin{array}{l}40 \\
(10)\end{array}$ & $\begin{array}{l}95 \\
(4)\end{array}$ & $\begin{array}{l}14 \\
(25)\end{array}$ & $\begin{array}{l}3 \\
(9)\end{array}$ & $\begin{array}{l}2 \\
(8)\end{array}$ \\
\hline Petroleum refining and extraction & $\begin{array}{l}434 \\
(12)\end{array}$ & $\begin{array}{l}200 \\
(8)\end{array}$ & $\begin{array}{l}476 \\
(6)\end{array}$ & $\begin{array}{l}1 \\
(12)\end{array}$ & $\begin{array}{l}3 \\
(8)\end{array}$ & $\begin{array}{l}0 \\
(6)\end{array}$ \\
\hline Prof. \& Scientific Equipment & $\begin{array}{l}278 \\
(9)\end{array}$ & $\begin{array}{l}72 \\
(4)\end{array}$ & $\begin{array}{l}972 \\
(10)\end{array}$ & $\begin{array}{l}35 \\
(9)\end{array}$ & $\begin{array}{l}34 \\
(4)\end{array}$ & $\begin{array}{l}5 \\
(10)\end{array}$ \\
\hline Rubber, stone, glass, plastics & $\begin{array}{l}91 \\
(25)\end{array}$ & $\begin{array}{l}40 \\
(10)\end{array}$ & $\begin{array}{l}1251 \\
(4)\end{array}$ & $\begin{array}{l}11 \\
(25)\end{array}$ & $\begin{array}{l}2 \\
(8)\end{array}$ & $\begin{array}{l}35 \\
(3)\end{array}$ \\
\hline Textiles & $\begin{array}{l}89 \\
(12)\end{array}$ & $\begin{array}{l}9 \\
(2)\end{array}$ & -- & $\begin{array}{l}13 \\
(12)\end{array}$ & $\begin{array}{l}0 \\
(2)\end{array}$ & -- \\
\hline Miscellaneous & $\begin{array}{l}50 \\
(9)\end{array}$ & $\begin{array}{l}30 \\
(5)\end{array}$ & $\begin{array}{l}68 \\
(2)\end{array}$ & $\begin{array}{l}3 \\
(8)\end{array}$ & $\begin{array}{l}3 \\
(5)\end{array}$ & $\begin{array}{l}7 \\
(2)\end{array}$ \\
\hline All Industries & $\begin{array}{l}225 \\
(224)\end{array}$ & $\begin{array}{l}329 \\
(105)\end{array}$ & $\begin{array}{l}480 \\
(98)\end{array}$ & $\begin{array}{l}20 \\
(57)\end{array}$ & $\begin{array}{l}11 \\
(30)\end{array}$ & $\begin{array}{l}7 \\
(18)\end{array}$ \\
\hline Standard Deviation & 516 & 711 & 1137 & 57 & 30 & 18 \\
\hline Min $=0 ;$ Maximum $=$ & 4573 & 4378 & 7429 & 555 & 250 & 105 \\
\hline
\end{tabular}

Notes:

Patent figures refer to the average number of patents granted to firms within the five years up to and including the year of the antitrust charge. The number of firms is shown in parentheses. See Appendix for definitions of industries. 
TABLE 4

OLS REGRESSIONS: DETERMINANTS OF PATENTING

(1) ALL FIRMS

Dependent Variable: Log of Patent Stock

\begin{tabular}{|c|c|c|c|}
\hline & $(1)$ & (2) & (3) \\
\hline Intercept & $\begin{array}{l}140.15 * * * \\
(9.33)\end{array}$ & $\begin{array}{l}150.27 * * * \\
(9.00)\end{array}$ & $\begin{array}{l}149.84^{* * *} \\
(14.77)\end{array}$ \\
\hline Year & $\begin{array}{l}-0.07 * * * \\
(9.31)\end{array}$ & $\begin{array}{l}-0.08 * * * \\
(8.97)\end{array}$ & $\begin{array}{l}-0.08 * * * \\
(10.16)\end{array}$ \\
\hline $\log (\mathrm{R} \& \mathrm{D})$ & $\begin{array}{l}0.42^{* * * *} \\
(5.13)\end{array}$ & $\begin{array}{l}0.43^{* * * *} \\
(4.36)\end{array}$ & $\begin{array}{l}0.36 * * * \\
(4.44)\end{array}$ \\
\hline Log(R\&D, one lag) & $\begin{array}{c}0.01 \\
(0.10)\end{array}$ & $\begin{array}{c}0.01 \\
(0.07)\end{array}$ & $\begin{array}{l}-0.02 \\
(1.25)\end{array}$ \\
\hline Log(R\&D, two lags) & $\begin{array}{l}-0.05 \\
(0.61)\end{array}$ & $\begin{array}{c}0.03 \\
(0.78)\end{array}$ & $\begin{array}{c}0.10 \\
(1.26)\end{array}$ \\
\hline Log(R\&D) Squared & $\begin{array}{l}0.03 * * * \\
(3.02)\end{array}$ & $\begin{array}{l}0.03^{* * * *} \\
(2.56)\end{array}$ & $\begin{array}{l}0.02 * * * \\
(2.44)\end{array}$ \\
\hline Log(Total Assets) & $\begin{array}{l}0.23 * * * \\
(5.33)\end{array}$ & $\begin{array}{l}0.24 * * * \\
(4.82)\end{array}$ & $\begin{array}{l}0.30 * * * \\
(6.73)\end{array}$ \\
\hline Antitrust dummy & $\begin{array}{l}0.56 * * * \\
(3.73)\end{array}$ & $\begin{array}{l}0.50 * * * \\
(3.18)\end{array}$ & $\begin{array}{l}0.55 * * * \\
(3.74)\end{array}$ \\
\hline Sales Growth & -- & $\begin{array}{l}-0.05 \\
(0.29)\end{array}$ & --- \\
\hline Log(Advertising Expenditures) & --- & $\begin{array}{l}-0.01 \\
(0.26)\end{array}$ & --- \\
\hline Proxy for Tobin's Q & -- & $\begin{array}{c}0.06 \\
(0.82)\end{array}$ & --- \\
\hline \multicolumn{4}{|l|}{ INDUSTRY EFFECTS } \\
\hline Chemicals and drugs & & & $\begin{array}{l}0.59 * * * \\
(3.07)\end{array}$ \\
\hline Petroleum & & & $\begin{array}{l}-0.31 \\
(1.19)\end{array}$ \\
\hline Materials technology & & & $\begin{array}{c}0.29 \\
(1.32)\end{array}$ \\
\hline Metals & & & $\begin{array}{l}0.61 * * * \\
(2.83)\end{array}$ \\
\hline Automobiles & & & $\begin{array}{l}0.79 * * * \\
(3.46)\end{array}$ \\
\hline Communications & & & $\begin{array}{l}0.71 * * * \\
(3.33)\end{array}$ \\
\hline Professional equipment & & & $\begin{array}{l}1.08 * * * \\
(3.91)\end{array}$ \\
\hline Food & & & -0.24 \\
\hline $\mathbf{N}$ & 657 & 603 & 657 \\
\hline $\mathbf{R}^{2}$ & $0.63^{* * *}$ & 0.60 & $0.66 * * *$ \\
\hline
\end{tabular}

Notes: Absolute value of t-statistics are in parentheses. * indicates significance at the 5 percent level; *** indicates significance below 5 percent level. See Appendix for industrial composition. The antitrust dummy has a value of 1 for antitrust sample, 0 for control. 
TABLE 4 (cont'd)

OLS REGRESSIONS: DETERMINANTS OF PATENTING

(2) ANTITRUST AND CONTROL SAMPLES

Dependent Variable: Log of Patent Stock

(1)

CONTROL SAMPLE

Intercept

Year

$\log (\mathrm{R} \& D)$

$\log (R \& D$, one lag)

$\log (R \& D$, two lags)

$\log (R \& D)$ Squared

Log(Total Assets)

INDUSTRY EFFECTS

Chemicals and drugs

Petroleum

Materials technology

Metals

Automobiles

Communications

Professional equipment

Food

$\mathrm{N}$

$\mathbf{R}^{2}$
$120.35 * * *$

(6.51)

$-0.06 * * *$

(6.51)

$0.49 * * *$

(4.94)

0.03

(0.26)

$-0.04$

(0.34)

$0.10 * * *$

(5.33)

$0.19 * * *$

(3.49)

0.25

(1.06)

$-1.00 * * *$

(3.11)

$-0.17$

$(0.61)$

$0.51 *$

(1.96)

0.50

(1.70)

0.40

(1.47)

$1.06 * * *$

(2.96)

$-0.34$

(1.42)

290

$0.49 * * *$
(2)

\section{ANTITRUST SAMPLE}

$184.44^{* * *}$

(8.38)

$-0.09 * * *$

(8.37)

$0.35^{* * *}$

(2.77)

0.02

$(0.15)$

0.09

$(0.81)$

0.01

$(0.58)$

$0.40 * * *$

(5.90)

$0.77^{* * *}$

(2.70)

0.19

$(0.47)$

0.61

(1.88)

0.58

(1.75)

$0.93 * * *$

(2.80)

$0.73 * * *$

(2.29)

$1.10^{* * *}$

(2.81)

$-0.18$

$(0.65)$

366

$0.59 * * *$

Notes: Absolute value of $t$-statistics are in parentheses. * indicates significance at the 5 percent level; indicates significance below 5 percent level. See Appendix for SIC composition of industry dummies. 
regression is estimated over antitrust firms alone. It is interesting that the $R \& D$ coefficients are more important for the control sample, probably due to greater variation across the non-antitrust firms unobserved by measurement error.

As is generally found, firms in the chemical, metal, automobile, computer and communications, and professional equipment industries experience higher patenting relative to those in traditional industries such as lumber, paper products, food and textiles, but industry effects do not add much explanatory power to the equation. The second part of the table reports regressions that allow coefficients to vary across both samples. As suggested by the simple statistics, the total assets or firm size elasticity of patenting is twice as high for the antitrust firms. Interindustry differences in patenting are evident across the samples, since companies in the control sample operating in the petroleum, automobile, computer and communications, chemical and pharmaceutical industries are not particularly prolific in terms of patent ownership. In sum, these results are consistent with the idea that antitrust firms tend to be larger and more innovative than other members of their industry who were not the subject of antitrust charges. The next section considers whether the likelihood of antitrust litigation varies with the degree of innovation.

\section{ANTITRUST AND INNOVATION: EMPIRICAL RESULTS}

Previous sections presented data and cases that indicate an increase over time in the importance of federal government antitrust charges relative to private cases. The recent attention of federal agencies to high technology firms also raised the possibility that the significance of patent/antitrust issues has increased since 1970. An examination of simple 
statistics on patenting seems to suggest that firms with higher patenting records are more likely to face charges of violating antitrust laws. However, these findings did not control for other factors that might influence antitrust litigation, such as profitability, advertising, and size of the firm. Therefore, in this section I use the firm level dataset described above to present multivariate analyses of factors that may influence the probability that a corporation will be involved in antitrust litigation. The major hypothesis being tested is whether firms with higher patenting profiles are more likely to experience antitrust litigation after controlling for other factors that might influence antitrust scrutiny.

Official reports by the federal antitrust agencies correctly point out that firms have rarely been charged directly with antitrust violations based on patent issues. However, the pattern in Figure 4 suggests that the issue is worth exploring further. The data were obtained from a search of the Lexis-Nexis federal lawsuits files (GENFED/OMNI) and include both private and federal government antitrust cases. I selected all lawsuits in which the words patent and antitrust occurred at least six times as an index of patent-antitrust cases, and computed the ratio of this index to all cases in which "antitrust" appeared at least six times (the patterns are not especially sensitive to the frequency chosen). The figure suggests that there was a decline in the importance of patent and antitrust issues until the middle of the 1970s, and a sharp increase thereafter until at least 1993. This is consistent with the fact that, at the same time that patent legislation guarded the rights of patentees against infringing competitors, a number of landmark restraint of trade lawsuits that involved technological innovators were being brought in these years. ${ }^{27}$

Table 5 reports logit regressions that were estimated first across all firms, then by 
Figure 4

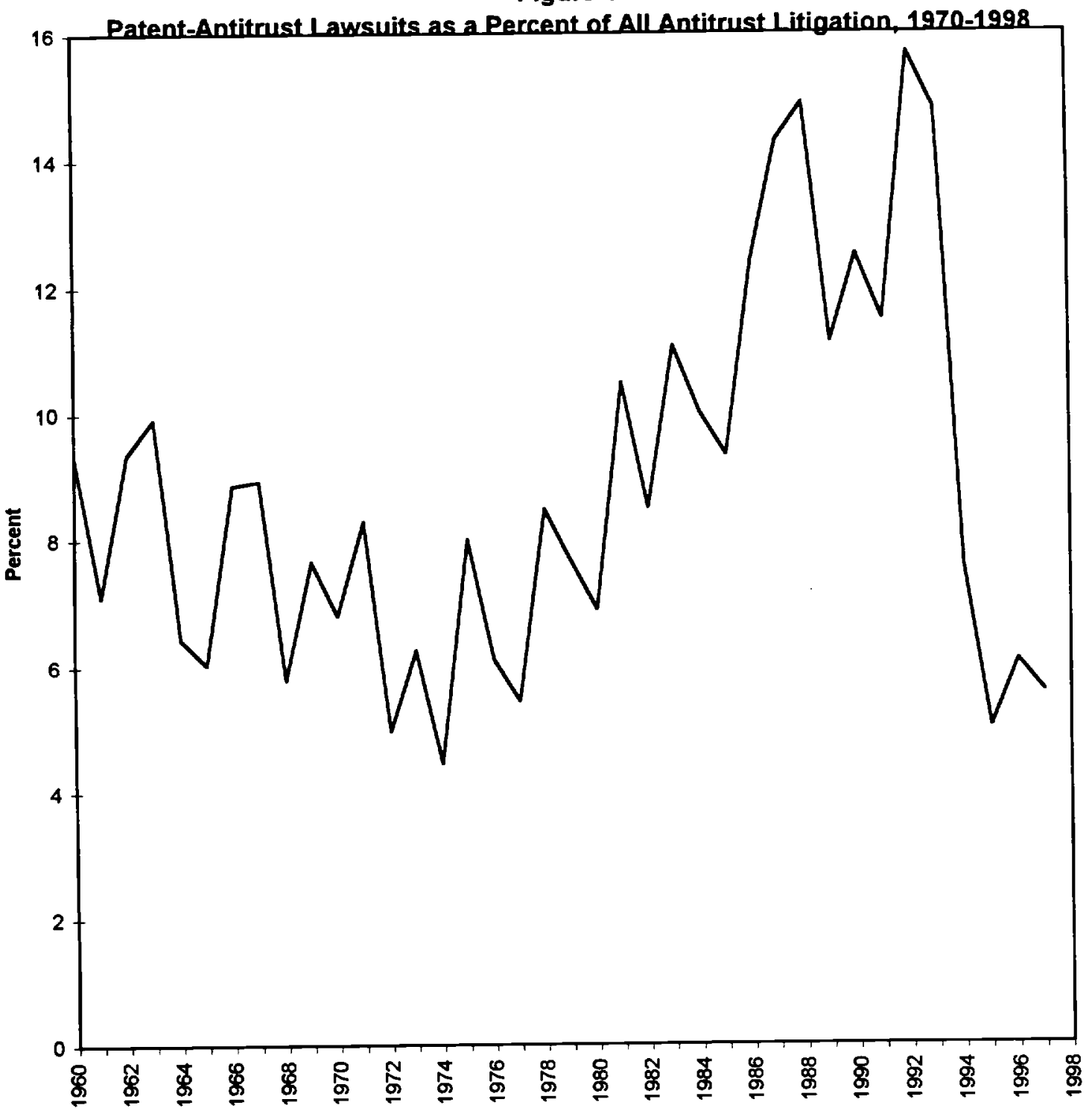

Notes: See text for details. 
size of firm. The dependent variable is a binary variable which has a value of 0 if the firm had not been involved in an antitrust case since 1950, and 1 if the firm had been charged by federal agencies between 1970 and the present. Coefficients are interpreted as the effect of a one unit change in the independent variable on the log of the odds of antitrust litigation. I use the log of $R \& D$ and patent stock to investigate the relationship between innovation and antitrust. Interestingly, research and development expenditures do not affect the likelihood of an antitrust action being brought against the firm, which suggests that innovative inputs are not as important as outputs such as patents, perhaps because the impact on market share of engaging in R\&D is negligible or not discernible. ${ }^{28}$

Antitrust ruling regarding patent stocks is quite clear: "Mere accumulation of patents, no matter how many, is not in and of itself illegal," United States v. United Shoe Machinery Corp., 110 F. Supp. 295 (D. Mass. 1953). United Shoe was found guilty because of its questionable business practices, not because of its extensive patent holdings. In the absence of anticompetitive behaviour, we should therefore find no relationship between patent stocks and the likelihood of antitrust charges. However, the patent stock coefficient is consistently positive and significant, and is likewise not sensitive to outliers, nor to variations in the sample size or time period. Given the relationship between firm size and patenting, it is important to control for the former, and several different specifications were tried. When we control for firm size the magnitude of the patent coefficient falls noticeably, but the variable remains statistically significant across all alternative specifications. ${ }^{29}$

The regressions also attempt to control for the influence of intangible assets and of market power through a number of proxies. Capital intensity and accounting measures of 
TABLE 5

LOGIT REGRESSIONS OF THE LIKELIHOOD OF ANTITRUST LITIGATION

(1) ALL FIRMS

Dependent Variable: 0 if control, 1 if antitrust litigation

(1)

$\begin{array}{lc} & \\ & \\ \text { Intercept } & 25.90 \\ & (1.63) \\ \text { Year } & 0.01 \\ & (1.47) \\ \text { Log(Patent Stock) } & 0.57 * * * \\ & (175.01)\end{array}$

Log(Total Assets)

$\log (R \& D)$

$\log (R \& D$, one lag)

$\log (R \& D$, two lags)

$R \& D=0$ dummy

Log(Advertising Expenditures)

Sales Growth

Proxy for Tobin's Q

N 786

$\mathrm{Chi}^{2}$

249.0
(2)

(3)

42.78
$(2.70)$
-0.02
$(2.97)$
$0.22 * * *$
$(12.85)$

45.93

(2.34)

$-0.03$

(2.87)

$0.21 * * *$

(8.32)

$0.82 * * *$

$0.81^{* * *}$

(99.84)

(78.46)

0.47

$(0.07)$

$-0.01$

(0.07)

$-0.02$

$(0.01)$

$-0.03$

(0.01)

(4)

(5)

$\begin{array}{ll}39.90 & 58.22 \\ (1.70) & (3.24) \\ -0.02 & -0.03^{*} \\ (2.15) & (3.84) \\ 0.24 * * * & 0.20^{* * *} \\ (10.57) & (7.18)\end{array}$

$0.75^{* * *}$

$0.81 * * *$

(63.60)

(64.16)

$-0.13$

(0.37)

0.12

$(0.23)$

$-0.03$

(0.03)

0.03

(0.01)

$-0.14$

(0.47)

0.04

(0.02)

0.17

$(0.01)$

$-0.13$

(0.24)

$\begin{array}{ll}0.20^{* * *} & 0.20^{* * *} \\ (5.27) & (4.91) \\ 1.52^{* * *} & 1.15 \\ (6.59) & (3.45) \\ & 0.28^{* * *} \\ & (4.72) \\ & 604 \\ 658 & \\ 349.1^{* * *} & 318.8^{* * *}\end{array}$

Notes: Wald Chi-squared statistics are in parentheses. * indicates significance at 5 percent level; *** indicates significance below 5 percent. See Appendix for definition and source of variables. 
TABLE 5 (cont'd)

LOGIT REGRESSIONS OF THE LIKELIHOOD OF ANTITRUST LITIGATION

(2) BY SIZE OF FIRM

Dependent Variable: 0 if control, 1 if antitrust litigation

\section{SMALL FIRMS}

$\log (R \& D)$

$\log (\mathrm{R} \& D$, one lag)

$\log (\mathrm{R} \& \mathrm{D}$, two lags)

$\mathrm{R} \& \mathrm{D}=0$ dummy

Log(Patent Stock)

Log(Total Assets)

Log(Advertising)

Sales Growth

Proxy for Tobin's Q

N

$\mathrm{Chi}^{2}$
(1)

84.62

(3.87)

$-0.04$

(4.29)

(1.72)

$-0.10$

(0.12)

$-0.26$

(1.31)

$-0.23$

(0.54)

0.07

(0.48)

$0.85 * * *$

(22.50)

$--$

--

(2)

77.01

(3.01)

$-0.04$

$(0.02)$

0.21

(0.41)

$-0.00$

(0.00)

$-0.31$

(1.61)

$-0.21$

$(0.46)$

0.10

(0.79)

$0.79 * * *$

(16.95)

0.12

(0.65)

1.50***

(4.54)

$--$

318

$47.0 * * *$

308

49.0
(3)

$113.80^{* * * *}$

(5.58)

$-0.06 * * *$

(6.08)

0.18

(0.57)

$-0.07$

(0.06)

-0.31 )

(1.62)

$-0.26$

(0.64)

0.05

$(0.24)$

$0.91 * * *$

(19.52)

0.10

(0.51)

1.00

(1.77)

$0.44 * * *$

$(7.40)$

298

$53.8 * * *$

\section{MEDIUM FIRMS}

(4)

(5)

6.78

3.14

(0.01)

(0.00)

$-0.01$

$-0.01$

(0.06)

$-0.23$

(0.43)

$-0.03$

$(0.03)$

$-0.52$

(1.84)

$-0.03$

(0.01)

(0.01)

0.19

0.28

(1.09)

$-0.37$

$-0.03$

(0.37)

(0.00)

$0.36 * * *$

(7.99)

(7.56)

1.24***

$1.24 * * *$

(13.67)

0.41 ***

(6.27)

1.43

(1.41)

0.20

$(0.47)$
207

$52.9 * * *$

Notes: Small firms have total real assets below $\$ 500$ million; medium firms between $\$ 500$ and $\$ 1000$ million; large firms above $\$ 1000$ million. Wald Chi-squared statistics are in parentheses. * indicates significance at 5 percent level; *** indicates significance below 5 percent. See Appendix for description and source of variables. 
intangible assets were not influential, and thus are not included in the reported regression. A standard proxy is advertising expenditures, which are positively related to the likelihood of antitrust charges. Firms with faster growth in sales are also more likely to be the subject of antitrust investigations. Rapid sales growth and excess market value may signal the presence of market power through innovation or in the form of rents to firm-specific assets. The results indicate that firms with higher sales growth and excess market values are more likely to be involved in antitrust, although the inclusion of both variables reduces the overall explanatory power of the regression.

The relationship between antitrust and innovation might vary depending on interactions between independent variables and firm size, but inclusion of interaction terms reduces the reliability of estimates because of collinearity. The second section of the table therefore shows separate regressions for smaller firms (those with real total assets below $\$ 500$ million) and medium firms (assets between $\$ 500$ million and $\$ 1000$ million). Similar patterns to those reported above hold for medium firms, except for the lack of influence of sales growth on the likelihood of antitrust charges. Patenting by smaller firms is not related to antitrust involvement (although this result only holds for a subset of this class). ${ }^{30}$ Advertising intensity is also not influential, but smaller firms with faster sales growth or higher excess market values are more likely to attract antitrust attention.

If it is indeed true that innovative or successful enterprises face a higher likelihood of antitrust litigation, one might expect that such firms would respond by changing the rate and direction of their inventive activity. This is a difficult issue to determine empirically, but some evidence is available in the area of R\&D alliances. Thus, the next section provides 
another perspective on the relationship between antitrust policies and innovation. For, it examines the filing of research joint ventures and concludes that innovative businesses seem to perceive and even overestimate the likelihood of charges or convictions under antitrust laws.

\section{COOPERATIVE RESEARCH AND ANTITRUST}

The National Cooperative Research Act (1984) and the National Cooperative Research and Production Act (NCRPA, 1993) were approved because policy makers were concerned about the role of antitrust in the declining competitiveness of American technology relative to foreign firms that seemed to benefit from research consortia. ${ }^{31}$ Commentators explicitly opined that technological innovation would be enhanced if collaboration in $R \& D$ endeavours were freed from the inhibition of possible antitrust liabilities, and pointed to longstanding Japanese and European laws which grant such joint ventures antitrust exemptions. Thus, the NCRPA was "designed to promote research and development, encourage innovation, stimulate trade, and make necessary and appropriate modifications in the operation of the antitrust laws. ${ }^{.32}$ The acts clarified the antitrust implications of R\&D joint ventures, and offered relief from costs and fees in unsuccessful antitrust actions. They also recommended the application of the rule of reason to all joint ventures, although the incremental benefit of such a provision is arguably minimal relative to existing policy. Further, joint ventures that filed a notification with the antitrust agencies were sheltered from the recovery of treble damages in private and state antitrust lawsuits, because the 
statute limited liability in such cases to single damages. These modifications were apparently motivated by the "overdrawn yet real perception in the business community that the antitrust laws generally discourage all collaborative activity."${ }^{133}$ This section considers the membership of NCRPA joint ventures that registered with the DOJ, and is based on unpublished reports that the DOJ presents annually to the Committee on the Judiciary.

A total of 609 joint ventures were filed with the DOJ between 1985 and 1996. Of these, 124 joint R\&D ventures were formed between 1985 and 1988, and some 200 ventures registered between 1988 and 1993. Approximately 250 R\&D cooperative associations registered under the 1993 statute between June 1993 and 1996. The most recent report for 1996 to 1997 indicates that 63 new $R \& D$ joint ventures registered over the period, while 55 existing ventures updated the status of their membership or activities. Thus the NCRPA has been associated with rapid growth in the formation of research consortia and/or the propensity to register these associations formally to obtain lower private antitrust damages. The responsiveness of innovative firms to a statute that in effect only offers protection from treble damages seems to suggest an extremely high perceived probability of charges and conviction incident on participation in joint ventures. The number of filings with the DOJ is therefore consistent with the idea that businesses perceive some degree of conflict between antitrust and innovation.

Table 6 presents descriptive statistics for a cross-section of joint ventures filed in three years, which was assembled as part of a separate and more detailed study of the effects of the NCRPA. European joint ventures tend to be concentrated in the high technology areas of chemicals, biotechnology, information technology and new materials 
TABLE 6

CHARACTERISTICS OF NCRPA MEMBERSHIP

\begin{tabular}{|c|c|c|c|c|}
\hline \multirow[b]{2}{*}{ Industry } & \multicolumn{3}{|c|}{ INDUSTRIAL DISTRIBUTION } & \multirow[b]{2}{*}{ Percent } \\
\hline & $\begin{array}{l}\text { Number of } \\
\text { Joint Ventures }\end{array}$ & Percent & Number of Firms & \\
\hline \multicolumn{5}{|l|}{ Chemical, Medical } \\
\hline \& Pharmaceutical & 13 & 12.5 & 92 & 5.9 \\
\hline Computers & 23 & 22.1 & 866 & 55.2 \\
\hline Energy and Power & 15 & 14.4 & 119 & 7.6 \\
\hline \multicolumn{5}{|l|}{ Electronics and } \\
\hline Related Durables & 13 & 12.5 & 153 & 9.8 \\
\hline Motor Vehicles & 18 & 17.3 & 191 & 12.2 \\
\hline Telecommunications & 6 & 5.8 & 46 & 2.9 \\
\hline Other & 16 & 15.4 & 100 & 6.4 \\
\hline TOTAL & 104 & 100.0 & 1567 & 100.0 \\
\hline TYPE OF FIRM & Number & Percent & & \\
\hline Foreign firms & 298 & 19.0 & & \\
\hline \multicolumn{5}{|l|}{ University and } \\
\hline other Non-Corporate & 110 & 7.0 & & \\
\hline U.S. Corporations & 1159 & 74.0 & & \\
\hline
\end{tabular}

REGIONAL DISTRIBUTION OF FIRMS IN SAMPLE

$\begin{array}{lcr}\text { Region } & \text { Number of Firms } & \text { Percent } \\ \text { New England } & 18 & 10.3 \\ \text { Mid-Atlantic } & 29 & 16.6 \\ \text { Midwest } & 49 & 28.0 \\ \text { South } & 34 & 19.4 \\ \text { West } & 45 & 25.7\end{array}$

FEDERAL ANTITRUST INVOLVEMENT OF NCRPA SAMPLE

\begin{tabular}{|c|c|c|c|}
\hline & $\begin{array}{l}\text { Sample } \\
\text { No. Firms }\end{array}$ & $\begin{array}{l}\text { Antitrust } \\
\text { No. Firms }\end{array}$ & $\begin{array}{l}\text { Percent involved } \\
\text { in Antitrust }\end{array}$ \\
\hline \multicolumn{4}{|l|}{ Chemical, Medical } \\
\hline \& Pharmaceutical & 26 & 6 & 23.1 \\
\hline Computers & 46 & 16 & 34.8 \\
\hline Energy and Power & 28 & 10 & 35.7 \\
\hline Electronics and & 24 & 5 & 20.8 \\
\hline \multicolumn{4}{|l|}{ Related Durables } \\
\hline Motor Vehicles & 18 & 8 & 44.4 \\
\hline Telecommunications & 9 & 1 & 11.1 \\
\hline TOTAL & 151 & 46 & 30.5 \\
\hline
\end{tabular}

Notes: From Annual Reports on R\&D joint venture filings, DOJ (unpublished, various years). The sample comprises two firms from each venture that filed in three randomly selected years. Antitrust involvement relates to federal government charges. 
technology. In this country, the Computer and Business Equipment Manufacturers Association had been a strong advocate for the passage of the NCRPA legislation. It is therefore not surprising that the sample of joint ventures is dominated by the large number of firms that participated in research alliances related to the computer industry (both hardware and software). The majority of these NCRPA firms were American corporations from the Midwest region (in consortia largely related to automotive research) and the West, although the DOJ reports participation by representatives from over 30 foreign countries. A number of joint ventures included partnerships between universities and corporations, such as the 1996 "Blue Band II Consortium" to develop semiconductor laser diodes, which included among its members Hewlett Packard, Xerox Palo Alto Research Center, SDL Inc, Boston University, MIT, and the Universities of New Mexico, Texas, and Utah.

It is undoubtedly true that firms collaborate in research for a number of reasons besides antitrust considerations. For instance, they may benefit from complementarities in knowledge and other inputs, from economies of scale, the internalization of spillovers, risk sharing and access to other markets. However, these are reasons for engaging in shared endeavours rather than for registration with the federal antitrust agencies. It is possible to gain some insight into the link between antitrust enforcement and the tendency to register joint R\&D activities by considering the antitrust history of member firms. I therefore analyzed the federal antitrust records of a random sample of member firms that filed under the NCRPA. As Table 6 indicates, almost one third of the sample had been charged with antitrust violations by either the DOJ or the FTC. Hence, the perception by innovative businesses that collaborations would likely attract antitrust scrutiny may not be greatly 
"overdrawn" given their past experience.

Antitrust agencies and federal courts over the years have undoubtedly modified their attitude towards technologically motivated alliances in relation to trade restraint. ${ }^{34}$ Nevertheless, there have been several prominent cases recently of firms jointly charged with antitrust violations that are linked to patent based market power and to concerns about "innovation markets". ${ }^{35}$ This is most clearly shown in the prominent role that patents and R\&D have played in recent mergers under section 7 of the Clayton Act, administered by the FTC. The FTC challenged the proposed Roche and Genentech merger in 1990 and required Roche to license its patents on therapeutics for growth hormone deficiency to third parties. Similarly, in 1994 the FTC was troubled by the technological implications of a merger between Sensormatic Electronics and the Knogo Corporation, both of which produce electronic surveillance source labels to protect against shoplifting. ${ }^{36}$ The two firms planned to grant each other royalty free cross-licences and to share trade secrets. The FTC claimed that the agreement would lessen competition, and the market was unlikely to attract entry "because of patent protection for important technology and the time required to develop the requisite technical skills to compete." Moreover, the merger would serve to "increase the likelihood that firms in the relevant market will restrict output of research and development both in the near future and in the long term." The consent decree prohibited Sensormatic from acquiring patents belonging to Knogo, and imposed a ten year ban on Sensormatic's purchasing similar patents. The Sensormatic case treated patented technologies as products, without considering the increase in net social welfare that might accrue if firms formed joint ventures for the purpose of sharing knowledge and expertise, 
and avoiding duplicative efforts.

The majority of current patent-antitrust cases arise in the context of proposed mergers and acquisitions, rather than in the context of predatory behaviour or per se illegal actions. Consent decrees in these cases typically require a combination of technology divestures, compulsory licensing, and even the forced sharing of trade secrets to ensure that competitors are able to acquire the capability to effectively use the technology. ${ }^{37}$ In Wright Medical Technology, the FTC ordered the firm to transfer patents, trade secrets and business know-how related to orthopaedic finger implants to the Mayo Foundation. ${ }^{38}$ The agency further stipulated that the latter should be able to sublicense these assets in perpetuity, and that Wright Medical was then required to provide technical assistance to the Mayo sublicensee (a future competitor of Wright).

\section{CONCLUSION}

The issue of interactions between patenting, innovation and antitrust enforcement has generated a longstanding debate typically supported by references to case studies. This paper was motivated by the marked lack of empirical attention paid to the issue of patenting in relation to antitrust actions brought by federal government agencies. I outlined patterns of aggregate antitrust activity, which indicated a fall in both private and government antitrust litigation, but an increase in the relative importance of government actions. A rough estimate of the frequency of patent-antitrust interactions suggested an increase since 1970, which could be due to the greater economic importance of technology intensive industries, or to greater government scrutiny of innovative firms. It seems plausible that 
firm specific effects would explain a greater part of the variation in antitrust charges than industry effects, so my sample was constructed to examine within-industry variation.

The major finding of the empirical analysis is that patent stocks are associated with higher likelihood of antitrust charges for medium and larger firms. Smaller firms with faster sales growth, possibly an index of greater success, are also likely to sustain greater antitrust litigation. The results are consistent with the hypothesis that innovative, successful enterprises are more likely to garner antitrust attention, especially since recent FTC rulings express concern about protecting competition in the "market for innovation". These findings may also explain the previous reluctance of firms to engage in research alliances because of fears of antitrust charges. However, the results do not control for other elements of firm strategy that might be correlated with patenting behaviour and sales growth. For instance, the evidence on intellectual property litigation could be taken as an indication that innovative firms might be more aggressive in their pursuit of market share. Such firms might also have a greater tendency to engage in anticompetitive behaviour.

Additional research could be directed towards providing more information on the nature of the charges brought, since the implications of the findings would differ in the case of (say) merger challenges relative to price fixing charges. In further work I intend to consider directly the nature of antitrust cases that involve patent issues, and to examine the antitrust and innovation implications of NCRPA filings more extensively. It would also be interesting to explore differences in innovation policies between the FTC and DOJ. For instance, I conducted interviews with officials at both agencies whose comments implied that the FTC is more likely to bring a charge at the instigation of market rivals (it was argued 
that private firms can at times act as surrogate Attorneys General), whereas the DOJ selects cases that are likely to be economically important and precedent setting. 


\section{A. DEFINITION AND SOURCE OF VARIABLES}

\section{VARIABLE}

R\&D Intensity Advertising Intensity Capital Intensity Profit Rate Real Total Assets Sales Growth Small Firms Medium Firms Large Firms

Excess Market Valuation

Intellectual Property Litigation

Patent Stock

NCRPA Firms

Antitrust Firms

\section{DEFINITION}

Compustat R\&D/Total Assets

Compustat Advertising Expenditures/Total Assets

Compustat Capital Expenditures/Total Assets

Compustat Net Income/Total Assets

Total Assets deflated by Producer Price Index, 1982 $=100$

Compustat Sales variable; one year and two year growth

Real Total Assets below $\$ 500$ million

Real Total Assets between $\$ 500-\$ 1000$ million

Real Total Assets above $\$ 1000$ million

[(Current Assets - Current Liabilities + Long Term Debt $)+$ (Common Stock Outstanding*Price of Stock + Preferred Stock)] Total Assets

[All variables from Compustat]

Searches by firm in Lexis/Nexis (PATENT/IPOMNI) for total count of lawsuits involving patents, trademarks or copyrights.

Patents granted to firm in five years prior to antitrust charge. Source: Patent Office Gazette for patents filed before 1971, the IBM Patent Searcher website for 1971-1975, and Lexis/Nexis (PATENT/UTIL) for patents 1975-1998.

Annual reports provided by the Department of Justice, 1986 through 1997 (details regarding membership in research joint venture under the National Cooperative Research and Production Act). The sample of firms comprises two members that were randomly chosen from each venture for the years 1987, 1996 and 1997; thus small ventures are over-represented.

See text for sources. 


\section{B. CONTROL SAMPLE}

The antitrust sample was randomly matched by year and 4-digit SIC code with a control sample. Each antitrust firm was allocated to an industry based on the product market that was the subject of the antitrust charge. Hence, the product market was not necessarily the firm's main line of business. I obtained a list of firms on Compustat that were in that product market in the same year as the charge. Next, these firms were checked against antitrust records on Lexis/Nexis, and those that had been involved in federal antitrust actions in the previous twenty years were eliminated. The final filter was to exclude those firms for which Compustat did not have any data for the years in question.

\section{STANDARD INDUSTRY CLASSIFICATIONS}

\section{INDUSTRY}

Automobiles \& other transportation Chemicals and pharmaceuticals Communications equipment

Food

Lumber and paper products

Materials

Metals

Machinery

Petroleum

Professional Equipment

Misc

Textiles

\section{SIC GROUPS}

37

28

$36,4810,4811$

20

$24,25,26$

$30,31,32$

33,34

35

29

38

$2111,2121,3480,39$

22,23 


\section{ENDNOTES}

1. See Khan, "Property Rights and Patent Litigation," Journal of Economic History, v. 55 (1) 1995: 58-97.

2. "Patentees are not monopolists ... A monopolist is one who, by the exercise of the sovereign power, takes from the public that which belongs to it, and gives to the grantee and his assigns an exclusive use. On this ground monopolies are justly odious ... Under the patent law this can never be done. No exclusive right can be granted for anything which the patentee has not invented or discovered. If he claim anything which was before known, his patent is void, so that the law repudiates a monopoly. The right of the patentee rests entirely on his invention or discovery of that which is useful, and which was not known before. And the law gives him the exclusive use of the thing invented or discovered, for a few years, as a compensation for 'his ingenuity, labor, and expense in producing it.' This, then, in no sense partakes of the character of a monopoly." Allen v. Hunter, 6 McLean 303 (1855), cited in Khan (1995), p. 75.

3. The major antitrust legislation comprises the Sherman Act, ch. 647, 26 Stat. 209 (1890) (codified as amended at 15 U.S.C. @@ 1-7 (1982)); Clayton Act, ch. 323, 38 Stat. 730 (1914) (codified as amended at 15 U.S.C. @@12-27 (1982)); and Federal Trade Commission Act, ch. 311, 38 Stat. 717 (1914) (codified as amended at 15 U.S.C. @@ 41-58 (1982)).

4. See United States v. American Can Co., 256 U.S. 706 (1921), United States v. International Harvester Co., 274 U.S. 693 (1927), United States v. United States Steel Corp., 251 U.S. 417 (1920), United States v. United Shoe Mach. Co., 247 U.S. 32 (1918). See also W. BOWMAN, PATENT AND ANTITRUST LAW 120-256 (1973). More recent cases include the high-profile U.S. v Microsoft (1998) and U.S. v. Intel (1998).

5.Charles F. Rule, "Patent-Antitrust Policy: Looking Back and Ahead," Antitrust Law Journal, v. 59 1991: 729-37.

6. See William J. Baumol and Janusz A. Ordover, "Antitrust: Source of Dynamic and Static Inefficiencies?" in Jorde and Teece (1992):82-97.

7. For the "optimists' view", see Willard K. Tom and Joshua A. Newberg, "Antitrust and Intellectual Property: From Separate Spheres to Unified Field," Antitrust Law Journal, v. 66 (1) 1997: 167. A recent decision, Atari Games Corp. v. Nintendo of America, 897 F. 2d 1572, 1576 (1990), reflects this view: "the aims and objectives of patent and antitrust laws may seem, at first glance, wholly at odds. However, the two bodies of law are actually complementary, as both are aimed at encouraging innovation, industry and competition," (cited in Tom and Newberg, p. 88, n. 34). See also Shapiro and Willig (p. 124): "Nor is there evidence to support the view that U.S. antitrust policy stifles innovation by U.S. firms," in "On the Antitrust Treatment of Production Joint Ventures, JEP 4(3) 1990: 113-30. 


\section{See Bowman, Patent and Antitrust Law, p. 3.}

9. Staff Report to Subcommittee No. 5 of the House Committee on the Judiciary, 84th Congress 2d Session (1957), cited in Neil B. Siegel, "Patent Monopoly and Sherman Act Monopolization," JOPS v. 49 (2) 1967: 68-80. More recently, see the DOJ and FTC "Antitrust Guidelines for the Licensing of Intellectual Property," reprinted in 4 Trade Reg. Rep. (CCH) P 13,132. The basic declarations of the Guidelines are: the antitrust agencies will consider intellectual property to be the same as other forms of property; it will not be presumed that such property creates market power of the sort deprecated by antitrust laws; and they will ratify licensing agreements that generate economic benefits and further consumer welfare.

10. Summit Technology, Inc., Dkt. No. 9286 (complaint issued March, 1998).

11. Predatory innovation can include price fixing, prohibitive clauses in licences, unreasonable royalty terms, restricting competitors, and tying arrangements; there is some question as to whether it includes stockpiling patents that were purchased from others outside the firm in order to deter competitors. Ordover \& Willig, An Economic Definition of Predation: Pricing and Product Innovation, 91 YALE L.J. 8 (1981), p. 8, argue that "even genuine innovations -- new products that in some ways are superior to existing products in the eyes of both engineers and consumers -- are in some circumstances anticompetitive."

12. Examples include Long, Schramm and Tollison, JLE 1973; John Siegfried, JLE 1975 and Peter Asch, JLE 1975.

13. See, for instance, Barry R. Weingast and Mark J. Moran, "Bureaucratic Discretion or Congressional Control? Regulatory Policymaking by the Federal Trade Commission," JPE v. 91 1983: 800; and Roger L. Faith, Donald R. Leavens, and Robert D. Tollison, "Antitrust Pork Barrel," JLE v. 25 1982: 329.

14. See Thomas Krauper and Edward Snyder, "Private Antitrust Cases that Follow on Government Cases," in Lawrence White (ed) Private Antitrust Litigation: 329-370.

15. See Richard Posner, "A Statistical Study of Antitrust Enforcement," JLE (1970) for trends before 1970 .

16. Consent decrees were first used in 1906 to record antitrust settlements. A consent decree is an adjudicated agreement negotiated by the federal authorities and the defendant in civil antitrust lawsuits. The decree must be accepted by the courts to be in "the public interest" and is as legally binding as a judgment after a formal lawsuit. The agreement typically carries no presumption of guilt on the part of the defendant. The majority of federal antitrust cases are terminated by a consent decree rather than a judgement from a formal trial in court. 
17. Information on the FTC Global and Innovation Based Competition Hearings for 1995 is available on the FTC website (www.ftc.gov).

18. When there were multiple defendants, the sample selected only the first name mentioned in the list of defendants for each charge. The control sample was inspected to ensure that it did not include any of these other defendants in the case.

19. Inventive activity is typically measured by inputs into the technology production function such as research and development, or by outputs such as patented inventions. This is not identical to the concept of innovation, which refers to commercialization. However, I follow accepted practice by measuring innovation in terms of $R \& D$ and patenting.

20. I enclose this term in quotation marks because the general interpretation does not fully capture the subtleties of Schumpeter's analysis. For an empirical approach to Schumpeter's model, see Scherer (1984).

21. See Clair Wilcox, Public Policies Toward Business, Homewood, Illinois, R. D. Irwin, 1966, p. 172.

22. Fritz Machlup, The Political Economy of Monopoly, Baltimore, Johns Hopkins Press, 1952, p. 284.

23. See Zoltan J. Acs and David B. Audretsch, "Innovation and Market Structure," REStat 1987.

24. See Carl Kaysen and Donald F. Turner, Antitrust Policy, Cambridge, MA, Harvard University Press, 1959.

25. See for instance, Dawson Chemical Co. v. Rohm \& Haas, 448 U.S. 176, 215 (1980), which refers to the "long-settled view that the essence of a patent grant is the right to exclude ohters from profiting by the patented invention." United Shoe Mach. Corp. v. O'Donnell Rubber Products, 84 F. 2d. 383, 386 (1936): "it has long been settled that ... it is the privilege of any owner of property to use or not use it without question of motive."

26. Patents are clearly imperfect indicators of both inventive activity and innovation, because of well known defects such as the fact that many inventions are not patented, variation in the propensity to patent over time and across industries, fluctuations in the proportion of applications that are granted, and the high fraction of patents that are useless. However, many interesting and important findings have been associated with the analysis of patent data, including a strong relationship between patenting and productivity. See Griliches (1990) for a comprehensive discussion of the utility of patent statistics in the study of technological and economic change.

27. Burchfiel (1991) points out that "Significant departures from existing antitrust criteria have been required both in the definition of substitutes and the relevant product market for patented technology" and "A common misconception has been that a patent or copyright, 
a high market share, or a unique product that competitors are not able to offer suffices to demonstrate market power." The DOJ Antitrust Guide stated that patent pools require "particular scrutiny under the antitrust laws," (cited in U.S. v. Motor Vehicle Manuf. Assoc. of USA, 1982).

28. It might seem plausible to use a direct measure of market share; however market share data are likely to be of limited use since the data would require information on the share of firm's sales in the antitrust market, whereas most firms operate in several markets, and separate data are not available for the firm's sales in each market.

29. This result might vary depending on interactions between patenting and firm size, but inclusion of interaction terms reduces the reliability of the estimates because of collinearity. Intellectual property litigation was also significantly associated with higher antitrust litigation, but was excluded from the reported equations because litigation was collinear with the patent stock.

30. The finding that patent stocks are not influential is dominated by firms with assets between $\$ 200-\$ 500$ million. For firms with assets below $\$ 200$ million there is a significantly positive relationship between patenting and antitrust involvement.

31. See S. Rep. No. 427, 98th Congress, 2d Session 1. The National Cooperative Research Act of 1984 related to research and development joint ventures [P.L. 98-462, 98 Stat. 1815, cited in 15 USCS@4301]. It was later extended to include production joint ventures. According to the Act June 10, 1993, P.L. 103-42, @2, 107 Stat. 117, cited in 15 USCS @ 4301:

"(1) technological innovation and its profitable commercialization are critical components of the ability of the United States to raise the living standards of Americans and to compete in world markets.

(2) cooperative arrangements among nonaffiliated businesses in the private sector are often essential for successful technological innovation; and procompetitive cooperative innovation arrangements, and so clarification serves a useful purpose in helping to promote such arrangements.

(3) Purpose. It is the purpose of this Act ... to promote innovation, facilitate trade, and strengthen the competitiveness of the United States in world markets by clarifying the applicability of the rule of reason standard and establishing a procedure under which businesses may notify the Department of Justice and Federal Trade Commission of their cooperative ventures and thereby qualify for a single-damages limitation on civil antitrust liability."

32. Department of Justice, Antitrust Division, 49 FR 50121, December 261984 (my emphasis). The NCRA of 1984 made two primary provisions: "The first is a simple codification of the consensus view found in existing law that properly structured joint ventures will be judged under a rule of reason standard ... under the antitrust law... [Second] parties to a joint venture may disclose the nature of the venture to the antitrust enforcement agencies and thereby receive reduced damage exposure from civil suits based on the 
activities disclosed. Compliance with the reporting prcedures would not result in a "certification" that the venture is legal under the antitrust laws; thus, even with disclosure, a venture later shown to be anticompetitive could still be challenged through the traditional dual system of private and public enforcement and be subject to single damages." Committee on the Judiciary, 102 H. Rept. 972, 102d. Congress, October 1992, p. 7.

33. Report of the Committee on the Judiciary, House Rept. 102-972, 102d. Congress, October 1992, p. 7.

34. This evolution is discussed in U.S. v Motor Vehicle Manufacturing Association of U.S.A. (1982), in the context of a petition to modify a 1969 consent decree that settled a charge of conspiring to share research findings.

35. For example, see 116 FTC 1381, 116 FTC 1243, 1993 FTC Lexis 214.

36. In re. Sensormatic Electronics Corporation, 1994 FTC Lexis 274, File No. 941-0126.

37. See 116 FTC 1381 (1993): "ICI shall provide to the acquirer ... at no cost to the acquirer, such rights to technology, know-how, and technical assistance regarding PMMA and acrylic sheet process and applications technology as may be necessary for the acquirer of the properties to be divested to utilize the properties to be divested." See also recent cases involving General Motors, Boston Scientific, Ciba Geigy et al., Upjohn Co., and Baxter International. A 1995 FTC consent decree related to remedies for alleged abuses in standard setting by Dell in relation to its 481 patent, without any discussion of Dell's market power. The consent order prohibited Dell from enforcing its 481 patent for the remainder of its term. Hoechst's merger with Marion Merrell Dow was only permitted with the proviso that the firm waived the right to enforce certain of its patents, divested part of its intellectual property, and licensed others [Hoechst, C-3629, Dec. 1995]. Courts have generally supported reasonable royalty fees in such cases, but some monopolization suits do require defendants to issue royalty free licenses. Moreover, defendants in some consent decrees have accepted royalty-free licensing stipulations.

38. Wright Medical Technology, C-3564, March 1995. 


\section{BIBLIOGRAPHY}

Acs, Zoltan J. and David B. Audretsch, "Innovation, Market Structure and Firm Size," REStat v. 69 (4) 1987: 567-74.

Asch, Peter, "The Determinants and Effects of Antitrust Activity," JLE v. 17 1975: 575-581.

Baumol, William J. and Janusz A. Ordover, "Antitrust: Source of Dynamic and Static Inefficiencies?" in Jorde and Teece (1992):82-97.

Bowman, Ward, Patent and Antitrust Law, Chicago, University of Chicago Press, 1973.

Burchfiel, Kenneth J., "Patent Misuse and Antitrust Reform: 'Blessed be the Tie?', Spring 1991, 4 Harv. J. Law \& Tec 1.

Faith, Roger L., Donald R. Leavens, and Robert D. Tollison, "Antitrust Pork Barrel," JLE v. 25 1982: 329.

Griliches, Zvi, "Patent Statistics as Economic Indicators: A Survey," JEL v. 28 (Dec.) 1990: 1661-1707.

Griliches, Zvi, ed., R\&D, Patents and Productivity, Chicago, University of Chicago Press, 1984.

Griliches, Zvi, R\&D and Productivity: The Econometric Evidence, Chicago, University of Chicago Press, 1998.

Grossman, Gene and Carl Shapiro, "Research Joint Ventures: An Antitrust Analysis," JLEO v. 2 (2) Fall 1986: 315-37.

Heller, Michael A. and Rebecca S. Eisenberg, "Can patents deter innovation? The anticommons in biomedical research," Science v. 280 (5364) 1998: 698.

Hoerner, Robert J., "Patent-Antitrust: Dead or Alive? Patent Misuse: Portents for the 1990s," Antitrust Law Journal v. 59 1990-91: 687.

Hovenkamp, Herbert, "Technology, Politics, and Regulated Monopoly: An American Historical Perspective," Texas Law Review v. 62 (April) 1984: 1263.

Jorde, Thomas M., and David J. Teece (eds), Antitrust, Innovation and Competitiveness, New York, Oxford University Press, 1992.

Kamien, Morton I. and Nancy L. Schwartz, "Market Structure and Innovation: A Survey," JEL v. 13 (March) 1975: 1-37. 
Kaplow, Louis, "The Patent-Antitrust Intersection: A Reappraisal," Harvard Law Review v. 97 1984: 1813.

Kauper, Thomas E. and Edward A. Snyder, "Private Antitrust Cases that Follow on Government Cases," in Lawrence J. White (ed) Private Antitrust Litigation, Cambridge, MA, MIT Press, 1988: 329-370.

Kaysen, Carl and Donald F. Turner, Antitrust Policy, Cambridge, MA, Harvard University Press, 1959.

Khan, B. Zorina,"Property Rights and Patent Litigation in Early Nineteenth Century America," JEH v. 55 (March) 1995: 58-97.

Kitch, Edmund, "The Nature and Function of the Patent System," Journal of Law and Economics v. 20 1977: 265.

Liebowitz, S. J., and Stephen E. Margolis, "Should Technology Choice be a Concern of Antitrust Policy?" Harvard J. of Law \& Tech. v. 9 (Summer) 1996: 283.

Long, William F., Richard Schramm, and Robert Tollison, "The Economic Determinants of Antitrust Activity," JLE v. 16 1973: 351-363.

Machlup, Fritz, The Political Economy of Monopoly, Baltimore, Johns Hopkins Press, 1952.

Merges, Robert P. and Richard R Nelson, "On the Complex Economics of Patent Scope," Columbia Law Rev. v. 90 (May) 1990: 839.

Ordover, Janusz and Robert D. Willig, "Antitrust for High Technology Industries: Assessing Research Joint Ventures and Mergers," JLE v. 28 (2) 1985: 311-33.

Ordover, Janusz and Robert D. Willig, "An Economic Definition of Predation: Pricing and Product Innovation," Yale Law Journal v. 91 (8) 1981.

Posner, Richard A., "A Statistical Study of Antitrust Enforcement," Journal of Law and Economics, v. 13 (Oct) 1970: 365-419.

Priest, George, "Cartels and Patent Licensing Arrangements," JLE v. 201977.

Rule, Charles F., "Patent-Antitrust Policy: Looking Back and Ahead," Antitrust Law Journal, v. 59 1991: 729-37.

Scherer, F. M., "How U.S. antitrust can go astray: The brand name prescription drug litigation," International Journal of the Economics of Business, v. 4 (November) 1997: 239-256. 
Shapiro, Carl and Robert D. Willig, "On the Antitrust Treatment of Production joint ventures," JEP 4(3) 1990: 113-129.

Siegel, Neil B., "Patent Monopoly and Sherman Act Monopolization," JOPS v. 49 (2) 1967: 68-80.

Siegfried, John J., "The Determinants of Antitrust Activity," JLE v. 17 1975: 559-573.

Silverman, Alexander E., "Myth, Empiricism, and America's Competitive Edge: The Intellectual Property Antitrust Protection Act," Stanford Law Rev. v. 43(July) 1991: 1417.

Tom, Willard K. and Joshua A. Newberg, "Antitrust and Intellectual Property: From Separate Spheres to Unified Field," Antitrust Law Journal, v. 66 (1) 1997: 167.

Weingast, Barry R. and Mark J. Moran, "Bureaucratic Discretion or Congressional Control? Regulatory Policymaking by the Federal Trade Commission," JPE v. 91 1983: 800.

Wilcox, Clair, Public Policies Toward Business, Homewood, Illinois, R. D. Irwin, 1966. 